\title{
Analysis of Building Envelope Construction in 2003 CBECS
}

DW Winiarski

MA Halverson

W Jiang

June 2007

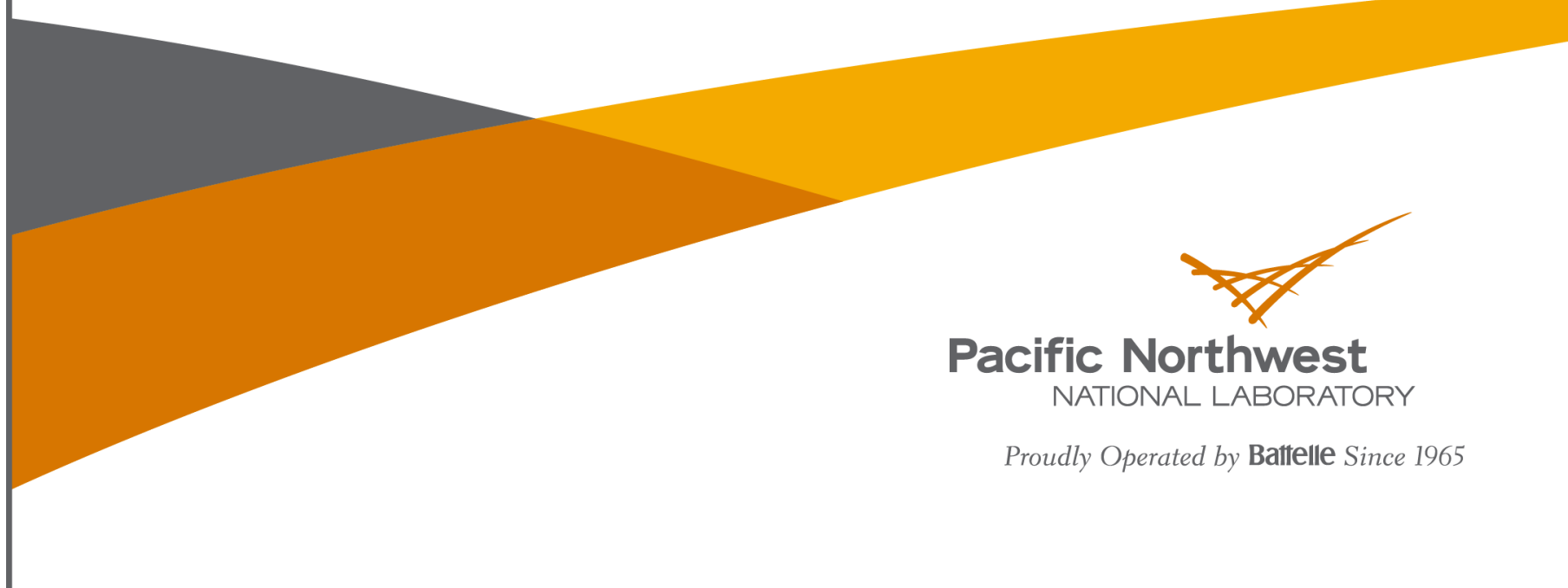




\title{
DISCLAIMER
}

This report was prepared as an account of work sponsored by an agency of the United States Government. Neither the United States Government nor any agency thereof, nor Battelle Memorial Institute, nor any of their employees, makes any warranty, express or implied, or assumes any legal liability or responsibility for the accuracy, completeness, or usefulness of any information, apparatus, product, or process disclosed, or represents that its use would not inf ringe privately owned rights. Reference herein to any specific commercial product, process, or service by trade name, trademark, manufacturer, or otherwise does not necessarily constitute or imply its endorsement, recommendation, or favoring by the United States Government or any agency thereof, or Battelle Memorial Institute. The views and opinions of authors expressed herein do not necessarily state or reflect those of the United States Government or any agency thereof.

\author{
PACIFIC NORTHWEST NATIONAL LABORATORY \\ operated by \\ BATTELLE \\ for the \\ UNITED STATES DEPARTMENT OF ENERGY \\ under Contract DE-AC05-76RL01830
}

Printed in the United States of America
Available to DOE and DOE contractors from the
Office of Scientific and Technical Information
P.O. Box 62, Oak Ridge, TN 37831-0062;
ph: (865) 576-8401
fax: $(865) 576-5728$
email: reports@adonis.osti.gov

Available to the public from the National Technical Information Service

5301 Shawnee Rd., Alexandria, VA 22312

ph: (800) 553-NTIS (6847)

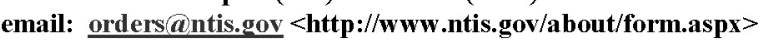

Online ordering: http://www.ntis.gov

This document was printed on recycled paper. 


\section{Analysis of Building Envelope Construction in 2003 CBECS}

DW Winiarski

MA Halverson

W Jiang

June 2007

Prepared for

the U.S. Department of Energy

under Contract DE-AC05-76RL01830

Pacific Northwest National Laboratory

Richland, Washington 99352 



\section{Summary}

The purpose of this analysis is to determine "typical" building envelope characteristics for buildings built after 1980. We address three envelope components in this paper - roofs, walls, and window area. These typical building envelope characteristics were used in the development of DOE's Reference Buildings ${ }^{1}$.

\section{Roofs}

The mapping of the U.S. Department of Energy's (DOE's) Energy Information Administration's 2003 Commercial Building Energy Consumption Survey (CBECS) (DOE EIA 2003) roof descriptions to American Society of Heating, Refrigerating and Air Conditioning Engineers (ASHRAE) Standard 90.12004 roof constructions for post-1980 vintage buildings is fairly robust. The recommended roof constructions are shown in Table S.1.

Table S.1. Recommended Roof Constructions by Building Type (Post-1980 buildings)

\begin{tabular}{ll}
\hline \multicolumn{1}{c}{ DOE Commercial Reference Building Type } & ASHRAE Standard 90.1-2004 Roof Construction \\
\hline Large Office, Medium Office, Stand-Alone Retail, & Insulation Entirely Above Deck \\
Primary School, Secondary School and University, & \\
Grocery Store, Hospital, and Hotel & \\
Small Office, Fast Food, Restaurant, Outpatient & Attic and Other \\
Health Care, and Motel & \\
Warehouse & Metal Building Roof \\
\hline
\end{tabular}

\section{Walls}

The mapping of 2003 CBECS wall descriptions to ASHRAE Standard 90.1-2004 wall constructions for post-1980 vintage buildings is much less robust because the vast majority of commercial wall area falls into a single CBECS description of brick, stone, stucco that can be mapped to all four of the ASHRAE Standard 90.1-2004 wall constructions. Data from the PNNL New Commercial Construction Characteristics dataset was used to supplement CBECS analysis. The recommended wall constructions are shown in Table S.2.

Table S.2. Recommended Wall Constructions by Building Type (Post-1980 buildings)

\begin{tabular}{ll}
\hline \multicolumn{1}{c}{ DOE Commercial Reference Building Type } & ASHRAE Standard 90.1-2004 Wall Construction \\
\hline Small Office, Grocery Store, Hospital, and Hotel & Mass Wall \\
Medium Office, Primary School, Secondary School & Steel Frame Wall \\
and University, Restaurant, Outpatient Health Care, & \\
and Motel & \\
\hline
\end{tabular}

\footnotetext{
${ }^{1}$ DOE Reference Buildings were developed as part of DOE's Commercial Building Initiative. The Reference buildings provide typical building models for approximately $70 \%$ of the commercial buildings in the US. See http://www1.eere.energy.gov/buildings/commercial_initiative/reference buildings.html for more detail.
} 


\begin{tabular}{ll}
\hline Fast Food & Wood Frame Wall \\
Warehouse & Metal Building Wall \\
Large Office and Stand-Alone Retail & Professional Judgment - Steel Frame Wall or Mass \\
& Wall \\
\hline
\end{tabular}

\section{Windows}

The analysis of CBECS data also allowed the development of window-to-wall ratio (WWR) information that could be applied to the development of the post-1980 Reference buildings. A number of detailed tables are supplied at the end of this document related to glazing. (These are not repeated in this Summary due to their size and complexity. See Table 4.6, Table 4.7, Table 4.8, and Table 4.9 for more details). The most significant result is the average WWR by building type as shown in Table S.3.

Table S.3. Average Window-to-Wall Ratio by Building Type

\begin{tabular}{clc}
\hline $\begin{array}{c}\text { DOE } \\
\text { Reference } \\
\text { Number }\end{array}$ & \multicolumn{1}{c}{ Reference Building Type } & $\begin{array}{c}\text { Average } \\
\text { WWR }\end{array}$ \\
\hline 1 & Large Office & $54 \%$ \\
2 & Medium Office & $31 \%$ \\
3 & Small Office & $19 \%$ \\
4 & Warehouse & $6 \%$ \\
5 & Stand-Alone Retail & $11 \%$ \\
6 & Strip Mall & NA \\
7 & Primary School & $22 \%$ \\
8 & Secondary School and University & $22 \%$ \\
9 & Grocery Store & $7 \%$ \\
10 & Fast Food & $34 \%$ \\
11 & Restaurant & $24 \%$ \\
12 & Hospital & $27 \%$ \\
13 & Outpatient Health Care & $21 \%$ \\
14 & Motel & $24 \%$ \\
15 & Hotel & $34 \%$ \\
\hline
\end{tabular}




\section{Acronyms and Abbreviations}

AFO

ANSI

ASHRAE

BSS

CBECS

CBP

DOE

EQGLS

GLSSPC

IESNA

$\mathrm{NC} 3$

NREL

PBAplus

PCCP

PNNL

PRS

SMP

SSTS

STS

WLCNS

WSSO

WWR

asphalt, fiberglass, other shingles

American National Standards Institute

American Society of Heating, Refrigerating and Air Conditioning Engineers

brick, stone, stucco

Commercial Building Energy Consumption Survey

concrete, block or poured

U.S. Department of Energy

equal glass

glass percentage

Illuminating Engineering Society of North America

New Commercial Construction Characteristics

National Renewable Energy Laboratory

Principle Building Activity Plus

pre-cast concrete panel

Pacific Northwest National Laboratory

plastic, rubber, synthetic

sheet metal panels

siding, shingles, tiles, shakes

slate, tile shingles

wall construction

wood shingles, shakes, other

window-to-wall ratio 



\section{Contents}

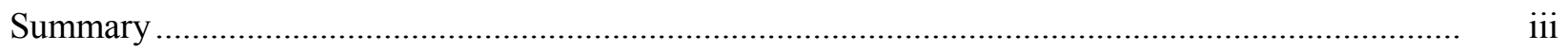

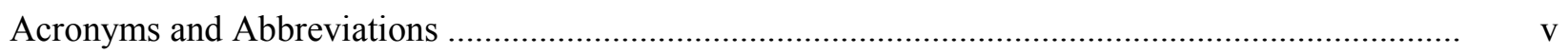

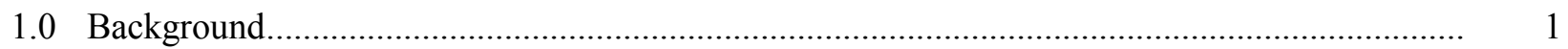

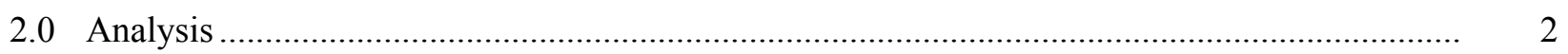

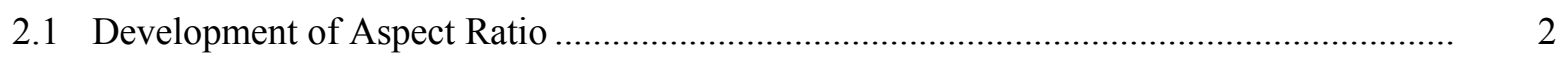

2.2 Assignment of WWR within CBECS categories …....................................................... 3

2.3 Development of Number of Stories ............................................................................ 3

2.4 Cross Checking of Floor-to-Floor Height by Building Type …....................................... 5

2.5 Development of Building Footprint …….................................................................. 5

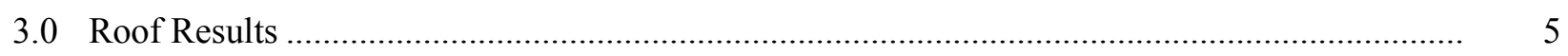

3.1 Mapping of CBECS Descriptors to ASHRAE Standard 90.1-2004 Roof Types................. 7

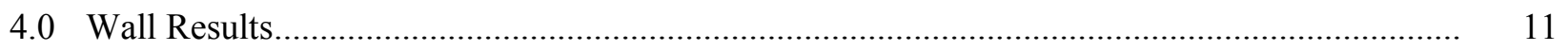

4.1 Mapping of CBECS Descriptors to ASHRAE Standard 90.1-2004 Wall Types ................ 13

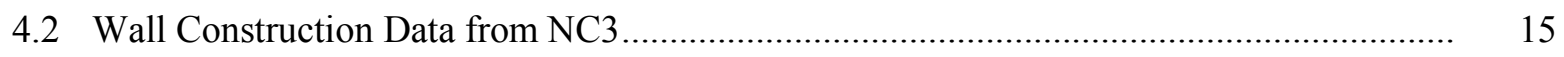

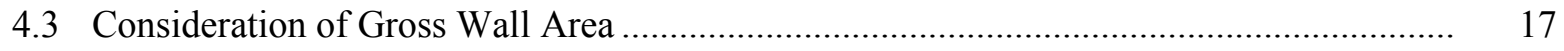

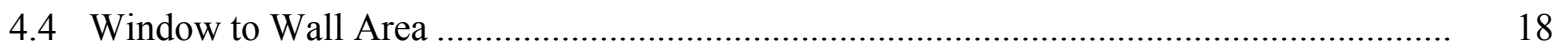

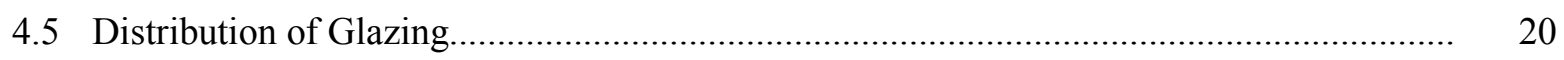

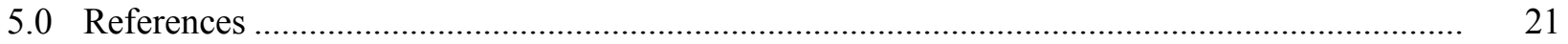

Appendix A - Development of Aspect Ratio Data for Odd Shaped Building ................................. A.1 


\section{Figures}

2.1 Probability Curve of Building Height for Tall Buildings

\section{Tables}

1.1 2003 CBECS Shortcomings and Approaches Taken to Address Those Shortcomings............... 1

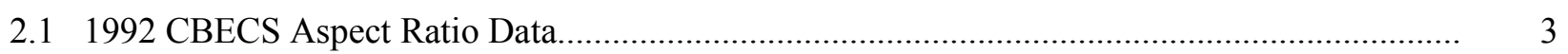

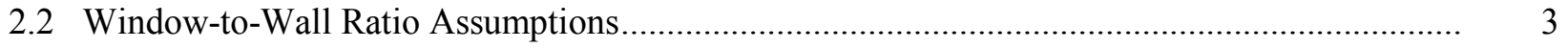

2.3 Estimating Number of Floors for CBECS Buildings......................................................... 5

3.1 Roof Descriptions by Reference Building Category.............................................................. 6

3.2 Relationship of CBECS Roof Descriptions to ASHRAE Standard 90.1 Roof

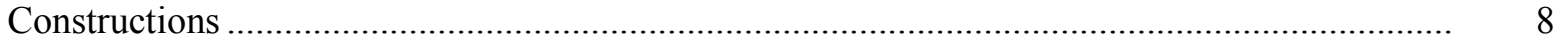

3.3 90.1-2004 Roof Constructions by Reference Buildings ........................................................ 9

3.4 Proposed Roof Constructions by Reference Building ........................................................ 10

4.1 Wall Descriptions by Reference Building .......................................................................... 11

4.2 Relationship of CBECS Wall Descriptions and ASHRAE Standard 90.1 Wall

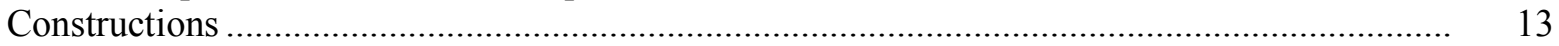

4.3 PNNL Proposed Wall Constructions Mapped to DOE Reference Buildings ............................ 15

4.4 NC3 Wall Type Most Common 90.1 Wall Construction Type Results....................................... 16

4.5 Proposed Wall Constructions by Building Type Based on CBECS and NC3 Data ................... 17

4.6 Fraction of Total Wall Area in Reference Building Category in Buildings Reporting 'Glass' for Wall Construction Material ..................................................................................... 18

4.7 Window-to-Wall Area Fraction for Post-1980 Buildings .......................................................... 19

4.8 Fraction of Buildings in Each Window-to-Wall Ratio Bin........................................................ 19

4.9 Distribution of Glazing for Post-1980 Buildings ............................................................... 20 


\subsection{Background}

The US Department of Energy (DOE) is in the process of developing a series of Reference prototypical buildings for use in tracking progress towards energy goals in buildings. ${ }^{1}$ Lawrence Berkeley National Laboratory (LBNL), the National Renewable Energy Laboratory (NREL), and Pacific Northwest National Laboratory (PNNL) have been tasked with developing these Reference buildings for both new and existing construction. DOE has tasked Pacific Northwest National Laboratory (PNNL) with developing characterization data on building envelopes, drawn from DOE's Energy Information Administration's 2003 Commercial Building Energy Consumption Survey (CBECS). (DOE EIA 2003)

This whitepaper presents the results of an analysis of the building envelope characteristics reported in the 2003 CBECS, disaggregated to DOE's Commercial Reference building definitions (as listed in Deru and Griffith 2006). Only buildings constructed after 1980 are included in this whitepaper. A companion whitepaper addresses pre-1980 buildings. ${ }^{2}$

Data from the 2003 CBECS is used to the extent feasible. The 2003 CBECS is DOE's most current collection of reported commercial building characteristics, but there are a number of shortcomings in the data when it is used for the type of analysis conducted for this paper. These shortcomings are listed below in Table 1.1 and discussed in more detail in the text of the whitepaper. Also listed below are the approaches used to get around these shortcomings. These approaches are also discussed in more detail in the text of the white paper.

Table 1.1. 2003 CBECS Shortcomings and Approaches Taken to Address Those Shortcomings

\begin{tabular}{ll}
\hline \multicolumn{1}{c}{ 2003 CBECS Shortcomings } & \multicolumn{1}{c}{ Approach Taken in This Whitepaper } \\
\hline $\begin{array}{l}\text { Wall and roof descriptions describe only the } \\
\text { appearance or façade of the building, not the } \\
\text { underlying wall or roof structure }\end{array}$ & $\begin{array}{l}\text { Appearance or façade descriptions are mapped most probable } \\
\text { underlying wall or roof structure } \\
\text { Data from New Commercial Construction Characteristics } \\
\text { (NC3) dataset used to provide additional information }\end{array}$ \\
$\begin{array}{l}\text { No description of building shape } \\
\begin{array}{l}\text { Specific number of stories not available for } \\
\text { buildings above 14 stories (data is withheld to } \\
\text { protect the identity of specific buildings }\end{array}\end{array}$ & $\begin{array}{l}\text { Data from an inventory of US skyscrapers used to estimate } \\
\text { relative frequency of number of stories }\end{array}$ \\
$\begin{array}{l}\text { Specific window area or window area fraction not } \\
\text { provided }\end{array}$ & $\begin{array}{l}\text { Window area from categorical data provided, using mid- } \\
\text { points of categories. }\end{array}$ \\
\hline
\end{tabular}

Throughout this whitepaper, final recommendations for wall and roof types are made in terms of the wall and roof assembly descriptions used in American National Standards Institute (ANSI)/American Society of Heating, Refrigerating and Air Conditioning Engineers (ASHRAE)/Illuminating Engineering Society of North America (IESNA) Standard 90.1-2004. This standard provides the basis for development of DOE's new construction Reference Buildings and the same wall and roof assembly descriptions are used for pre-1980 buildings as well. While older ASHRAE Standards (such as

\footnotetext{
${ }^{1}$ DOE Reference Buildings were developed as part of DOE's Commercial Building Initiative. The Reference buildings provide typical building models for approximately $70 \%$ of the commercial buildings in the US. See http://wwwl.eere.energy.gov/buildings/commercial_initiative/reference buildings.html for more detail.

${ }^{2}$ D Winiarski, M Halverson and W Jiang, 2007, Analysis of Building Envelope Construction in 2003 CBECS: Pre1980 Buildings. PNNL-SA-55594.
} 
ANSI/ASHRAE/IESNA Standard 90A-1980 and ANSI/ASHRAE/IESNA Standard 90.1-1989) could be considered for use in describing post-1980 buildings, neither of these standards has roof or wall assembly descriptions.

Note that the choice of a wall or roof type for a Reference building has energy implications. Versions of ASHRAE Standard 90 (dating back to 90-75) do have different U-factor requirements for different types of walls and roofs. Simply as an example, ANSI/ASHRAE/IESNA Standard 90.1-2004 has a variation for roof U-factor of 0.034 to 0.065 (depending on roof type) in Zone 5 (typical of Chicago, IL). This same building in the same location would show a variation in wall U-factor of 0.089 to 0.123 (depending on wall type). Values for other climate zones and other standards will vary, but this standard and location show a variation of over $90 \%$ on roof $U$-factor and nearly $40 \%$ on wall $U$-factor.

\subsection{Analysis}

Data was extracted from the 2003 CBECS dataset and mapped to the commercial Reference building type using the CBECS Principle Building Activity Plus (PBAplus) information. Additionally, office buildings were divided into the categories of "small," "medium," and "large" based on the definitions originally proposed by the National Renewable Energy Laboratory (NREL) (small is defined as single story, medium as two to four stories, and large greater than four stories).

For the purpose of this analysis, each building in the 2003 CBECS data set is treated as a rectangular block, with a defined aspect ratio, and constant cross sectional area from bottom floor to top floor. The building footprint is used as a surrogate for roof area. The footprint, shape, and number of stories as well as the floor-to-floor height, are used to estimate the total wall area for each building. The window-towall-ratio (WWR) can then be used to estimate the window area and the total opaque wall area of the building. All building stories reported by CBECS were assumed to be above grade.

To determine the total roof area of the building, the footprint of the building is calculated from the reported floor area of the building and the number of stories. To determine the total opaque wall area of the building, the aspect ratio, WWR, floor-to-floor height, and number of floors must be estimated.

\subsection{Development of Aspect Ratio}

The 2003 CBECS asks questions about building shape (square, rectangular, other) but does not directly ask about aspect ratio ${ }^{1}$ of the building footprint. The 1992 CBECS (DOE EIA 1992) was the last CBECS to collect aspect ratio data (for square and rectangular buildings) and that data is used in this analysis. The aspect ratio used for each 2003 CBECS building in this analysis was calculated as:

(a) 1.0 for square building shape; (b) average aspect ratio data reported for the Principle Building Activity (PBA) category for rectangle building shapes based on 1992 CBECS, and (c) 4.0 for all other building shapes (T-shaped, L-shaped, H-shaped, E-shaped, U-shaped and 'other' shaped. Development of the latter assumption is discussed in the Appendix. The 1992 CBECS aspect ratio data is listed below in Table 2.1.

\footnotetext{
${ }^{1}$ Aspect ratio is the ratio of the long dimension of the building on the horizontal plane to the short dimension of the building in the same plane.
} 
Table 2.1. 1992 CBECS Aspect Ratio Data

\begin{tabular}{lclc}
\hline \multicolumn{1}{c}{1992 CBECS PBA } & $\begin{array}{c}\text { Aspect } \\
\text { Ratio }\end{array}$ & \multicolumn{1}{c}{ 1992 CBECS PBA } & $\begin{array}{c}\text { Aspect } \\
\text { Ratio }\end{array}$ \\
\hline Education & 2.51 & Nursing home & 1.30 \\
Food sales & 1.86 & Office/professional & 2.01 \\
Food services (restaurants) & 1.88 & Other & 3.04 \\
Health care (inpatient) & 2.09 & Public assembly & 1.88 \\
Health care (outpatient) & 1.73 & Public order and safety & 1.85 \\
Indoor parking garage & 1.81 & Religious worship & 1.93 \\
Laboratory & 2.23 & Vacant & 2.34 \\
Lodging (hotel/motel/dorm) & 2.93 & Warehouse (non-refrigerated) & 2.56 \\
Mercantile/services & 2.07 & Warehouse (refrigerated) & 2.95 \\
\hline
\end{tabular}

\subsection{Assignment of WWR within CBECS categories}

The 2003 CBECS asks questions about WWR and presents the results in five categories (WWR bins) in its Glass Percentage (GLSSPC) (percentage exterior glass) statistic. The midpoint of the range in each category was used as the typical WWR for the buildings in each category (Table 2.2). It is assumed that the value reported by CBECS is the average for all sides of the building. For this exercise, all buildings are assumed free standing.

Table 2.2. Window-to-Wall Ratio Assumptions

\begin{tabular}{cc}
\hline Reported Percent Exterior Glass & Assumed WWR \\
\hline $0-10 \%$ & $5.0 \%$ \\
$10-25 \%$ & $18 \%$ \\
$25-50 \%$ & $38 \%$ \\
$50-75 \%$ & $63 \%$ \\
$75-100 \%$ & $88 \%$ \\
\hline
\end{tabular}

\subsection{Development of Number of Stories}

The 2003 CBECS provides number of stories data for individual buildings. For buildings between 1 and 14 stories, the actual number of stories is reported. However, for buildings greater than 14 stories the information is provided in ranges to mask the actual identity of the building. Two fairly broad ranges of building height are provided in CBECS: 15 to 25 stories and greater than 25 stories.

To provide an estimate of actual number of stories in these buildings, PNNL used data from the tall buildings database accessed at www.skyscraperpage.com. ${ }^{1}$ This online database provides limited data available for queries of tall buildings all over the world. The complete database (53,010 structures) is not available for download and must be accessed from a website for online queries. Data is presented for a limited number of buildings at a time.

\footnotetext{
${ }^{1}$ This website - (www.skyscraperpage.com) - appears to contain a self-reported database of all the tall buildings in the US, presumably maintained by tall building enthusiasts and others interested in architectural issues.
} 
Because the skyscraper dataset only allows users to download information on 50 buildings at a time, sorted by building height, and because there are far more shorter buildings than taller buildings in the dataset, it would be extremely time consuming to develop a distribution of buildings by floor height that would capture all of the buildings of interest in the database for this analysis. Instead, PNNL developed a distribution of buildings by roof height and then used a typical floor-to-floor height developed from the same dataset to convert this to a distribution by number of stories. For this work, PNNL employed data on the tallest 4,548 U.S. buildings (existing and construction completed), as determined by building roof height, down to $67.4 \mathrm{~m}(219 \mathrm{ft})$ roof height. The building data was binned in 10 meter height bins, and the number of buildings in each bin tabulated. PNNL then developed a probability curve of building height for tall buildings (see Figure 2.1)

In addition, because CBECS does not ask any questions about the typical height of stories, PNNL calculated the average floor-to-floor height for all buildings in the data subset as $3.95 \mathrm{~m}(13 \mathrm{ft})$. Using this average floor-to-floor height, a second, relative probability distribution of the number buildings with a given number of stories was estimated for all buildings 15 stories and higher, where the sum of the relative probabilities of all buildings 15 stories or greater in height was 1.0. These relative probabilities were then used as weighting factors to develop average number of floors for buildings in the 15-25 story and greater than 25 story bins used by CBECS. The results are shown in Table 2.3.

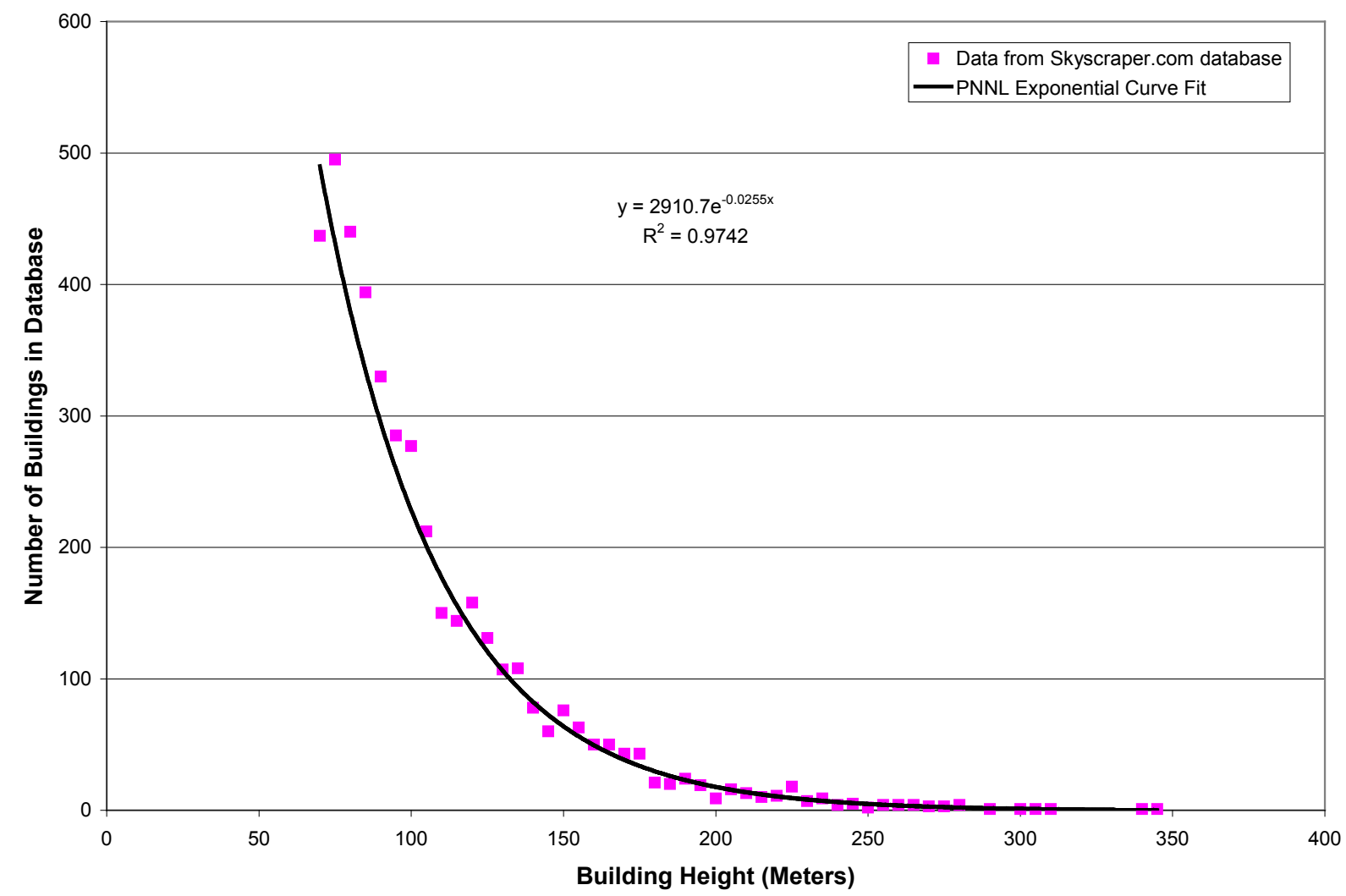

Figure 2.1. Probability Curve of Building Height for Tall Buildings 
Table 2.3. Estimating Number of Floors for CBECS Buildings

\begin{tabular}{cc}
\hline $\begin{array}{c}\text { CBECS Reported } \\
\text { Number of Floors Data }\end{array}$ & $\begin{array}{c}\text { Floors Assumed } \\
\text { for Building }\end{array}$ \\
\hline $1-14$ & Reported CBECS data \\
$15-25$ & 19 \\
26 or more & 35 \\
\hline
\end{tabular}

\subsection{Cross Checking of Floor-to-Floor Height by Building Type}

The estimated number of floors shown in Table 2.3 was based on an average floor height of $3.95 \mathrm{~m}$ (12.96 feet). This average was taken from a sample of 4,548 tall buildings that included 2,281 offices, 426 hotels, and 1,492 high-rise residential buildings (which are not part of CBECS). When all data were binned together in 0.2-meter bins, the 4.0- to 4.2-meter bin was the most common, followed by the 3.0- to 3.2-meter bin, indicating a bimodal distribution of floor heights. In an attempt to investigate the variation in floor-to-floor height by building type, the average floor-to-floor heights for offices, hotels, and highrise residential buildings were calculated separately. The average floor-to-floor heights were $4.2 \mathrm{~m}(13.8$

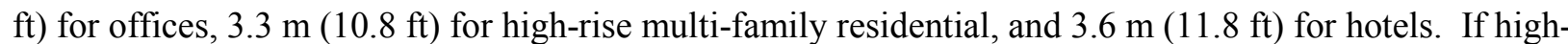
rise residential buildings are removed from the sample, the average floor-to-floor height would be $4.1 \mathrm{~m}$, which is slightly higher than the $3.95-\mathrm{m}$ estimate used. The impact on Table 2.3 of removing high-rise residential buildings from the sample would be to reduce the assumed number of floors to 18 for buildings of 15-25 stories and to 34 for buildings of 26 or more stories. Given other uncertainties in this data, these differences are not significant.

\subsection{Development of Building Footprint}

The footprint of each building was estimated as the reported building floor area divided by the number of stories (reported or estimated as above).

\subsection{Roof Results}

CBECS provides seven categories of roof construction material plus an "other" category and a "not one major type" category. For each Reference building type, Table 3.1 lists the top five most common roof descriptions, in decreasing order of occurrence, by percentage of roof area or fraction of buildings. Note that no consideration is given to the area of skylights. Roof area is assumed to correspond to the footprint of the building. This implies that roof area is more specifically projected roof area on the building footprint. PNNL did not attempt to estimate the relative increase in roof area for sloped roofs compared to flat roofs. 
Table 3.1. Roof Descriptions by Reference Building Category (Post-1980 Buildings)

\begin{tabular}{|c|c|c|c|c|c|}
\hline \multirow{2}{*}{$\frac{\text { Reference Number }}{1}$} & \multirow{2}{*}{$\begin{array}{c}\text { Reference } \\
\text { Building Type } \\
\text { Large Office }\end{array}$} & \multicolumn{2}{|c|}{$\begin{array}{l}\text { Roof Descriptions By } \\
\text { Fraction of Roof Area }\end{array}$} & \multicolumn{2}{|c|}{$\begin{array}{c}\text { Roof Descriptions by Fraction } \\
\text { of Buildings }\end{array}$} \\
\hline & & Built-Up & $48 \%$ & PRS & $41 \%$ \\
\hline & & PRS & $34 \%$ & Built-Up & $40 \%$ \\
\hline & & Concrete & $6 \%$ & $\mathrm{AFO}$ & $6 \%$ \\
\hline & & $\mathrm{AFO}$ & $6 \%$ & Concrete & $5 \%$ \\
\hline & & STS & $2 \%$ & STS & $4 \%$ \\
\hline \multirow[t]{5}{*}{2} & Medium Office & Built-Up & $34 \%$ & AFO & $36 \%$ \\
\hline & & PRS & $29 \%$ & Built-Up & $23 \%$ \\
\hline & & $\mathrm{AFO}$ & $21 \%$ & STS & $13 \%$ \\
\hline & & Metal & $9 \%$ & PRS & $11 \%$ \\
\hline & & STS & $4 \%$ & Metal & $10 \%$ \\
\hline \multirow[t]{5}{*}{3} & Small Office & Metal & $34 \%$ & $\mathrm{AFO}$ & $29 \%$ \\
\hline & & Built-Up & $21 \%$ & Metal & $29 \%$ \\
\hline & & AFO & $18 \%$ & Built-Up & $19 \%$ \\
\hline & & PRS & $15 \%$ & STS & $9 \%$ \\
\hline & & STS & $7 \%$ & PRS & $8 \%$ \\
\hline \multirow[t]{5}{*}{4} & Warehouse & Metal & $57 \%$ & Metal & $76 \%$ \\
\hline & & Built-Up & $21 \%$ & $\mathrm{AFO}$ & $10 \%$ \\
\hline & & PRS & $12 \%$ & Built-Up & $7 \%$ \\
\hline & & $\mathrm{AFO}$ & $6 \%$ & PRS & $3 \%$ \\
\hline & & Other & $1 \%$ & Concrete & $1 \%$ \\
\hline \multirow[t]{5}{*}{5} & Stand-alone Retail & Metal & $46 \%$ & Metal & $42 \%$ \\
\hline & & PRS & $22 \%$ & Built-Up & $20 \%$ \\
\hline & & Built-Up & $19 \%$ & AFO & $16 \%$ \\
\hline & & $\mathrm{AFO}$ & $6 \%$ & PRS & $8 \%$ \\
\hline & & Concrete & $6 \%$ & STS & $5 \%$ \\
\hline 6 & Strip Mall & NA & & NA & \\
\hline \multirow[t]{5}{*}{7} & Primary School & Built-Up & $32 \%$ & $\mathrm{AFO}$ & $31 \%$ \\
\hline & & Metal & $30 \%$ & Metal & $30 \%$ \\
\hline & & AFO & $17 \%$ & Built-Up & $25 \%$ \\
\hline & & PRS & $14 \%$ & STS & $9 \%$ \\
\hline & & STS & $4 \%$ & PRS & $4 \%$ \\
\hline \multirow[t]{5}{*}{8} & Secondary School and & Built-Up & $39 \%$ & AFO & $34 \%$ \\
\hline & University & PRS & $25 \%$ & Built-Up & $24 \%$ \\
\hline & & Metal & $18 \%$ & Metal & $23 \%$ \\
\hline & & $\mathrm{AFO}$ & $11 \%$ & PRS & $14 \%$ \\
\hline & & WSSO & $2 \%$ & STS & $3 \%$ \\
\hline \multirow[t]{5}{*}{9} & Grocery Store & PRS & $34 \%$ & AFO & $39 \%$ \\
\hline & & Built-Up & $22 \%$ & PRS & $17 \%$ \\
\hline & & $\mathrm{AFO}$ & $19 \%$ & Metal & $17 \%$ \\
\hline & & Metal & $17 \%$ & Built-Up & $14 \%$ \\
\hline & & STS & $6 \%$ & STS & $12 \%$ \\
\hline \multirow[t]{5}{*}{10} & Fast Food & PRS & $41 \%$ & PRS & $41 \%$ \\
\hline & & $\mathrm{AFO}$ & $23 \%$ & $\mathrm{AFO}$ & $23 \%$ \\
\hline & & Metal & $18 \%$ & Built-Up & $16 \%$ \\
\hline & & Built-Up & $14 \%$ & Metal & $10 \%$ \\
\hline & & Concrete & $4 \%$ & Concrete & $6 \%$ \\
\hline \multirow[t]{5}{*}{11} & Restaurant & Metal & $27 \%$ & Built-Up & $28 \%$ \\
\hline & & Built-Up & $22 \%$ & Metal & $23 \%$ \\
\hline & & PRS & $17 \%$ & $\mathrm{AFO}$ & $23 \%$ \\
\hline & & STS & $16 \%$ & STS & $12 \%$ \\
\hline & & $\mathrm{AFO}$ & $13 \%$ & PRS & $10 \%$ \\
\hline
\end{tabular}


Table 3.1. (contd)

\begin{tabular}{|c|c|c|c|c|c|}
\hline \multirow{2}{*}{$\frac{\text { Reference Number }}{12}$} & $\begin{array}{l}\text { Reference Building } \\
\text { Type }\end{array}$ & \multicolumn{2}{|c|}{$\begin{array}{l}\text { Roof Descriptions By } \\
\text { Fraction of Roof Area }\end{array}$} & \multicolumn{2}{|c|}{$\begin{array}{l}\text { Roof Descriptions by Fraction } \\
\text { of Buildings }\end{array}$} \\
\hline & Hospital & PRS & $45 \%$ & PRS & $42 \%$ \\
\hline & & Built-Up & $41 \%$ & Built-Up & $37 \%$ \\
\hline & & $\mathrm{AFO}$ & $8 \%$ & $\mathrm{AFO}$ & $12 \%$ \\
\hline & & Concrete & $3 \%$ & Concrete & $5 \%$ \\
\hline & & Metal & $3 \%$ & Metal & $4 \%$ \\
\hline \multirow[t]{5}{*}{13} & Outpatient Health & AFO & $40 \%$ & AFO & $43 \%$ \\
\hline & Care & Built-Up & $23 \%$ & Metal & $19 \%$ \\
\hline & & Metal & $16 \%$ & Built-Up & $16 \%$ \\
\hline & & PRS & $14 \%$ & STS & $11 \%$ \\
\hline & & STS & $6 \%$ & PRS & $7 \%$ \\
\hline \multirow[t]{5}{*}{14} & Motel & AFO & $41 \%$ & AFO & $61 \%$ \\
\hline & & STS & $23 \%$ & PRS & $13 \%$ \\
\hline & & Built-Up & $13 \%$ & STS & $12 \%$ \\
\hline & & PRS & $12 \%$ & Built-Up & $8 \%$ \\
\hline & & Metal & $9 \%$ & Metal & $6 \%$ \\
\hline \multirow[t]{5}{*}{15} & Hotel & $\mathrm{AFO}$ & $29 \%$ & $\mathrm{AFO}$ & $36 \%$ \\
\hline & & Built-Up & $28 \%$ & Metal & $19 \%$ \\
\hline & & PRS & $22 \%$ & Built-Up & $16 \%$ \\
\hline & & Metal & $12 \%$ & PRS & $16 \%$ \\
\hline & & STS & $6 \%$ & STS & $8 \%$ \\
\hline \multirow{3}{*}{\multicolumn{2}{|c|}{$\begin{array}{l}\text { PRS - Plastic, Rubber, Synthetic } \\
\text { STS - Slate, Tile Shingles } \\
\text { Metal - Metal Surfacing }\end{array}$}} & AFO - Asphalt, F & ss, Oth & & \\
\hline & & WSSO - Wood Sl & Shake & & \\
\hline & & Built-Up - Built- & ing & & \\
\hline
\end{tabular}

\subsection{Mapping of CBECS Descriptors to ASHRAE Standard 90.1-2004 Roof Types}

ASHRAE Standard 90.1-2004 defines three primary roof types based on the location of insulation relative to the roof: Insulation Entirely Above Deck, Metal Building, and Attic and Other. The primary assumption is that Insulation Entirely Above Deck has continuous insulation above the structural roof deck, while Metal Building has insulation compressed between structural members. In the Attic and Other roof type, insulation is laid between roof joists. A fourth secondary option for determining roof insulation levels in Standard 90.1-2004 is defined as single rafter roofs, a subclass of Attic and Other, where the roof above and the ceiling below are attached to the same rafter. For these assemblies, the requirement in Standard 90.1-2004 is the lesser of two values - the attic requirement or a separate requirement that essentially requires that the rafter cavity be filled with fiberglass insulation. For the purposes of this document, single-rafter roofs are classified as Attic and Other and given no further consideration.

Comparison of the three ASHRAE Standard 90.1-2004 roof types with the 2003 CBECS roof descriptions indicates that the only description that can be unambiguously mapped to a Standard 90.1 roof type is CBECS built-up classification mapping to 90.1's Insulation Entirely Above Deck. Slate, shingles, shakes, and tiles of any material map fairly unambiguously to Standard 90.1's Attic and Other category as these roofing materials are typically installed over an attic or single rafter roof. Less straightforward is the mapping of CBECS asphalt, fiberglass, other shingles (AFO) classification. This CBECS category can be mapped to 90.1's Attic and Other in the case of asphalt shingles, but can also be mapped to Insulation Entirely Above Deck in the case of a built-up roof with an asphalt top coat. The CBECS metal 
surface category can be mapped to 90.1 Metal Building, but can also indicate that a metal roof has been used in place of shingles over an attic roof structure. The CBECS PRS category most likely maps to the Insulation Entirely Above Deck category (mostly commonly where a synthetic membrane is placed over foam), although there are also commercially available recycled rubber and plastic shingles that would be installed over an attic. Table 3.2 shows the relationship of CBECS roof descriptions to ASHRAE Standard 90.1 roof constructions.

Table 3.2. Relationship of CBECS Roof Descriptions to ASHRAE Standard 90.1 Roof Constructions

\begin{tabular}{lccc}
\hline & \multicolumn{2}{c}{ ASHRAE Standard 90.1 Roof Construction } \\
\cline { 2 - 4 } \multicolumn{1}{c}{ CBECS Roof Descriptions } & $\begin{array}{c}\text { Insulation Entirely } \\
\text { Above Deck }\end{array}$ & $\begin{array}{c}\text { Metal } \\
\text { Building }\end{array}$ & $\begin{array}{c}\text { Attic and } \\
\text { Other }\end{array}$ \\
\hline asphalt, fiberglass, other (AFO) & $\mathrm{X}$ & & $\mathrm{X}$ \\
built-up & $\mathrm{X}$ & & $\mathrm{X}$ \\
concrete & & $\mathrm{X}$ & $\mathrm{X}$ \\
metal surfacing & & & \\
no one major type & & $\mathrm{X}$ \\
other & $\mathrm{X}$ & $\mathrm{X}$ \\
plastic, rubber, synthetic (PRS) & & $\mathrm{X}$ \\
slate, tile shingles (STS) & & \\
wood shingles, shakes, other(WSSO) & & & \\
\hline
\end{tabular}

The sum of the built-up and PRS categories shown in Table 3.2 (along with some fraction of the AFO category and assuming that use of recycled plastic and rubber shingles is rare in commercial buildings) probably provides an estimate of the number of built-up roofing or roofs with Insulation Entirely Above Deck according to ASHRAE. Metal surfacing may indicate metal building roofs or metal roofing over an attic depending on building type. All other CBECS roof descriptions are indicative of an attic roof.

Applying the assumptions in the previous paragraph to the data shown in Table 3.1 leads to the following statements.

- For warehouses, it is assumed that metal surfacing indicates a traditional Metal Building roof. This is the dominant roof type by area and by building for warehouses.

- For large offices, medium offices, secondary schools and universities, grocery stores, hospitals, and hotels, the combination of built-up and PRS descriptors indicates the use of a built-up roof and is therefore categorized as Insulation Entirely Above Deck. This combination covers anywhere from about $55 \%$ (grocery) to $85 \%$ (hospital) of the roof area for these Reference buildings.

- For fast food, the sum of PRS and built-up also 55\%, but a flat roof with insulation entirely above deck does not seem appropriate. An article on mansard roofs accessed at http://en.wikipedia.org/wiki/Mansard_roof indicates that many fast food roofs are Mansard, which essentially have an attic space covered with synthetic material. This reflects what is shown in Table 3.1 (a high percentage of PRS and relatively low percentage of built-up roofing). For this reason, PNNL would categorize fast food as Attic and Other.

- For small offices, the metal surface most likely represents a metal standing seam roof over an attic. Taking this into account, "attic-related" descriptors would account for about $60 \%$ of the area, while built-up roofs account for $36 \%$. Therefore, PNNL would categorize small offices would as Attic and Other. 
- For stand-alone retail, it is possible that the metal surface roof descriptor could refer to either a traditional Metal Building or to metal roofing over an attic. Because this is the single largest descriptor by building area and building count, whatever assumption is made on splitting the population of buildings reporting this descriptor will affect the overall choice of roof construction. There does appear to be about $40 \%$ of the roof area in built-up roofs and another $12 \%$ that would probably be attic, but the vast majority is either Metal Buildings or metal roofing over attics. Given that there are Metal Buildings that are stand-alone retail, but probably not a significant amount, most of the metal surface is probably over attics. This would indicate a split between built-up roofs and roofs with attics that is too close to call definitively, although attic may be slightly higher.

- For primary school, the split between attics and built-up roofs is almost an equal. It is not likely that the metal surface roof indicates Metal Building. The choice of roof type here will have to be left to professional judgment informed by other data.

- For restaurant, Metal surface would likely indicate metal roofing over an attic and therefore about $56 \%$ attics versus 38\% built-up roof. PNNL would categorize restaurant as Attic and Other.

- For outpatient healthcare, although significant metal surface is indicated, it is probably not Metal Building. Therefore, outpatient healthcare is about $62 \%$ attic versus $37 \%$ built-up. PNNL would categorize outpatient healthcare as Attic and Other.

- For motel, data shows $25 \%$ built-up roofs versus $73 \%$ attic. PNNL would categorize motel as Attic and Other.

Based on this mapping, Table 3.3 summarizes PNNL's recommendations for DOE's Commercial Reference buildings, based on CEBCS data and some professional judgment.

Table 3.3. 90.1-2004 Roof Constructions by Reference Buildings (Post-1980 Buildings, based on CBECS2003 data)

\begin{tabular}{cll}
\hline $\begin{array}{c}\text { Reference } \\
\text { Number }\end{array}$ & \multicolumn{1}{c}{ Reference Building Type } & \multicolumn{1}{c}{ Roof Construction } \\
\hline 1 & Large Office & Insulation Entirely Above Deck \\
2 & Medium Office & Insulation Entirely Above Deck \\
3 & Small Office & Attic and Other \\
4 & Warehouse & Metal Building \\
5 & Stand-Alone Retail & Split between Attics and Other and Insulation Entirely Above \\
& & Deck - No recommendation from CBECS \\
6 & Strip Mall & NA \\
7 & Primary School & Split between Attics and Other and Insulation Entirely Above \\
& & Deck - No recommendation from CBECS \\
9 & Secondary School and University & Insulation Entirely Above Deck \\
10 & Grocery Store & Insulation Entirely Above Deck \\
11 & Restaurant & Attic and Other \\
12 & Hospital & Attic and Other \\
13 & Outpatient Health Care & Insulation Entirely Above Deck \\
14 & Motel & Attic and Other \\
15 & Hotel & Attic and Other \\
\hline
\end{tabular}


In cases where CBECS does not offer sufficient guidance to assign a Reference building type to a particular roof construction, professional judgment or other sources of information must be used. One way for DOE to choose roof constructions is to have a policy of selecting either the most or the least stringent roof type. As noted in the Section 1.0, roofs with Insulation Entirely Above Deck are always subject to less stringent requirements than roofs with attics in ASHRAE 90.1-2004. This is a function of the ASHRAE requirements development process, which is based on strict cost-effectiveness assumptions and assumes that it is always cheaper to pour in cellulose or lay in more fiberglass insulation in an attic than it is to add continuous foam insulation to a roof deck. The differences in ASHRAE requirements for Insulation Entirely Above Deck and Attic and Other are significant in some cases. For example, in Climate Zone 6 (Minneapolis, Minnesota), the U-factor requirement for roofs with Insulation Entirely Above Deck is 0.063 and that for roofs with attics is 0.027 . In Climate Zone 1, the corresponding values are 0.063 and 0.034. The result is that the Insulation Entirely Above Deck has the highest U-factors and, therefore, the selection of Reference buildings with this type of roof will have slightly higher energy usage (all other things being equal) than for the same Reference building with other roof choices.

PNNL recommends implementation of the "least stringent" approach outlined above. The resulting proposed roof constructions are shown in Table 3.4.

Based on the discussion above, Table 3.4 shows the final recommendations for roof types.

Table 3.4. Proposed Roof Constructions by Reference Building (Post-1980 Buildings)

\begin{tabular}{cll}
\hline $\begin{array}{c}\text { Reference } \\
\text { Number }\end{array}$ & \multicolumn{1}{c}{ Reference Building Type } & \multicolumn{1}{c}{ Roof Construction } \\
\hline 1 & Large Office & Insulation Entirely Above Deck \\
2 & Medium Office & Insulation Entirely Above Deck \\
3 & Small Office & Attic and Other \\
4 & Warehouse & Metal Building \\
5 & Stand-Alone Retail & Insulation Entirely Above Deck \\
6 & Strip Mall & NA \\
7 & Primary School & Insulation Entirely Above Deck \\
8 & Secondary School and University & Insulation Entirely Above Deck \\
9 & Grocery Store & Insulation Entirely Above Deck \\
10 & Fast Food & Attic and Other \\
11 & Restaurant & Attic and Other \\
12 & Hospital & Insulation Entirely Above Deck \\
13 & Outpatient Health Care & Attic and Other \\
14 & Motel & Attic and Other \\
15 & Hotel & Insulation Entirely Above Deck \\
\hline
\end{tabular}




\subsection{Wall Results}

CBECS provides the Wall Construction (WLCNS) statistic as a classification of the major wall construction type for each building. The CBECS WLCNS categories are (a) brick, stone, or stucco (BSS); (b) concrete block or poured concrete (CBP); (c) decorative or construction glass; (d) pre-cast concrete panels (PCCP); (e) sheet metal panels (SMP); (f) siding, shingles, tiles, or shakes (SSTS); and (g) window or vision glass. CBECS also has classifications of (h) no one major type and (i) other. For each Reference building type, Table 4.1 lists the top five CBECS wall construction choices in decreasing order of occurrence by percentage of calculated total opaque wall area or number of buildings. Note that in determining the percentage of total opaque wall area, the window area for the building has been removed from the frequency statistic (i.e., total wall area). Some buildings have their primary wall construction in CBECS characterized as vision or construction glass, which is not an opaque wall construction. Thus these buildings tend to rank low on this list (compared to if we had ranked buildings by total wall area including glazed area).

Table 4.1. Wall Descriptions by Reference Building (Post-1980 Buildings)

\begin{tabular}{|c|c|c|c|c|c|}
\hline \multirow{2}{*}{$\begin{array}{c}\text { Reference } \\
\text { Number }\end{array}$} & \multirow{2}{*}{$\begin{array}{l}\text { Reference Building Type } \\
\text { Large Office }\end{array}$} & \multicolumn{2}{|c|}{$\begin{array}{c}\text { Wall Descriptions By } \\
\text { Fraction of Opaque Wall Area }\end{array}$} & \multicolumn{2}{|c|}{$\begin{array}{l}\text { Wall Descriptions by } \\
\text { Fraction of Buildings }\end{array}$} \\
\hline & & $\begin{array}{l}\text { BSS } \\
\text { PCCP } \\
\text { Vision Glass } \\
\text { CBP } \\
\text { Cons. Glass }\end{array}$ & $\begin{array}{l}44 \% \\
40 \% \\
4 \% \\
4 \% \\
3 \% \\
\end{array}$ & $\begin{array}{l}\text { BSS } \\
\text { PCCP } \\
\text { Vision Glass } \\
\text { CBP } \\
\text { Cons. Glass }\end{array}$ & $\begin{array}{l}48 \% \\
30 \% \\
8 \% \\
6 \% \\
5 \%\end{array}$ \\
\hline 2 & Medium Office & $\begin{array}{l}\text { BSS } \\
\text { CBP } \\
\text { SSTS } \\
\text { PCCP } \\
\text { SMP } \\
\end{array}$ & $\begin{array}{l}62 \% \\
10 \% \\
9 \% \\
8 \% \\
7 \% \\
\end{array}$ & $\begin{array}{l}\text { BSS } \\
\text { SSTS } \\
\text { CBP } \\
\text { SMP } \\
\text { PCCP }\end{array}$ & $\begin{array}{l}62 \% \\
11 \% \\
10 \% \\
7 \% \\
4 \% \\
\end{array}$ \\
\hline 3 & Small Office & $\begin{array}{l}\text { BSS } \\
\text { SSTS } \\
\text { SMP } \\
\text { CBP } \\
\text { PCCP }\end{array}$ & $\begin{array}{l}52 \% \\
19 \% \\
17 \% \\
5 \% \\
4 \% \\
\end{array}$ & $\begin{array}{l}\text { BSS } \\
\text { SSTS } \\
\text { SMP } \\
\text { CBP } \\
\text { PCCP }\end{array}$ & $\begin{array}{l}50 \% \\
26 \% \\
15 \% \\
4 \% \\
2 \%\end{array}$ \\
\hline 4 & Warehouse & $\begin{array}{l}\text { SMP } \\
\text { PCCP } \\
\text { BSS } \\
\text { CBP } \\
\text { SSTS }\end{array}$ & $\begin{array}{l}53 \% \\
14 \% \\
11 \% \\
11 \% \\
10 \% \\
\end{array}$ & $\begin{array}{l}\text { SMP } \\
\text { SSTS } \\
\text { BSS } \\
\text { CBP } \\
\text { PCCP }\end{array}$ & $\begin{array}{l}57 \% \\
13 \% \\
13 \% \\
8 \% \\
7 \%\end{array}$ \\
\hline 5 & Stand-alone Retail & $\begin{array}{l}\text { SMP } \\
\text { CBP } \\
\text { BSS } \\
\text { SSTS } \\
\text { PCCP }\end{array}$ & $\begin{array}{l}36 \% \\
28 \% \\
19 \% \\
9 \% \\
6 \% \\
\end{array}$ & $\begin{array}{l}\text { CBP } \\
\text { SMP } \\
\text { BSS } \\
\text { SSTS } \\
\text { PCCP }\end{array}$ & $\begin{array}{l}33 \% \\
28 \% \\
20 \% \\
14 \% \\
3 \%\end{array}$ \\
\hline 6 & Strip Mall & NA & & NA & \\
\hline 7 & Primary School & $\begin{array}{l}\text { BSS } \\
\text { SSTS } \\
\text { CBP } \\
\text { SMP } \\
\text { PCCP }\end{array}$ & $\begin{array}{l}48 \% \\
21 \% \\
17 \% \\
7 \% \\
2 \%\end{array}$ & $\begin{array}{l}\text { SSTS } \\
\text { BSS } \\
\text { CBP } \\
\text { SMP } \\
\text { Other }\end{array}$ & $\begin{array}{l}38 \% \\
32 \% \\
13 \% \\
12 \% \\
2 \%\end{array}$ \\
\hline
\end{tabular}


Table 4.1. (contd)

\begin{tabular}{|c|c|c|c|c|c|}
\hline $\begin{array}{l}\text { Reference } \\
\text { Number }\end{array}$ & Reference Building Type & $\begin{array}{l}\text { Wall Descriptio } \\
\text { Fraction of Opaque }\end{array}$ & $\begin{array}{l}\text { Nall By } \\
\text { Narea }\end{array}$ & $\begin{array}{l}\text { Wall Descript } \\
\text { Fraction of } \mathrm{Bl}\end{array}$ & \\
\hline 8 & $\begin{array}{l}\text { Secondary School and } \\
\text { University }\end{array}$ & $\begin{array}{l}\text { BSS } \\
\text { CBP } \\
\text { PCCP } \\
\text { SSTS } \\
\text { SMP }\end{array}$ & $\begin{array}{l}63 \% \\
14 \% \\
12 \% \\
5 \% \\
5 \%\end{array}$ & $\begin{array}{l}\text { BSS } \\
\text { SSTS } \\
\text { CBP } \\
\text { SMP } \\
\text { PCCP }\end{array}$ & $\begin{array}{l}55 \% \\
18 \% \\
15 \% \\
9 \% \\
4 \%\end{array}$ \\
\hline 9 & Grocery Store & $\begin{array}{l}\text { SMP } \\
\text { BSS } \\
\text { CBP } \\
\text { SSTS } \\
\text { PCCP }\end{array}$ & $\begin{array}{l}28 \% \\
25 \% \\
22 \% \\
16 \% \\
9 \%\end{array}$ & $\begin{array}{l}\text { SSTS } \\
\text { SMP } \\
\text { BSS } \\
\text { CBP } \\
\text { PCCP }\end{array}$ & $\begin{array}{l}27 \% \\
26 \% \\
26 \% \\
17 \% \\
4 \%\end{array}$ \\
\hline 10 & Fast Food & $\begin{array}{l}\text { BSS } \\
\text { SSTS } \\
\text { CBP } \\
\text { Vision Glass } \\
\text { Other } \\
\end{array}$ & $\begin{array}{l}71 \% \\
13 \% \\
10 \% \\
3 \% \\
3 \% \\
\end{array}$ & $\begin{array}{l}\text { BSS } \\
\text { CBP } \\
\text { SSTS } \\
\text { Other } \\
\text { PCCP }\end{array}$ & $\begin{array}{l}66 \% \\
14 \% \\
12 \% \\
3 \% \\
3 \%\end{array}$ \\
\hline 11 & Restaurant & $\begin{array}{l}\text { BSS } \\
\text { CBP } \\
\text { SSTS } \\
\text { SMP } \\
\text { PCCP }\end{array}$ & $\begin{array}{l}43 \% \\
21 \% \\
17 \% \\
12 \% \\
3 \%\end{array}$ & $\begin{array}{l}\text { BSS } \\
\text { CBP } \\
\text { SSTS } \\
\text { SMP } \\
\text { PCCP }\end{array}$ & $\begin{array}{l}48 \% \\
20 \% \\
17 \% \\
8 \% \\
4 \%\end{array}$ \\
\hline 12 & Hospital & $\begin{array}{l}\text { BSS } \\
\text { CBP } \\
\text { PCCP } \\
\text { SSTS } \\
\text { No Major Type }\end{array}$ & $\begin{array}{l}66 \% \\
15 \% \\
10 \% \\
7 \% \\
1 \% \\
\end{array}$ & $\begin{array}{l}\text { BSS } \\
\text { CBP } \\
\text { SSTS } \\
\text { PCCP } \\
\text { SMP }\end{array}$ & $\begin{array}{l}64 \% \\
13 \% \\
11 \% \\
10 \% \\
1 \%\end{array}$ \\
\hline 13 & Outpatient Health Care & $\begin{array}{l}\text { BSS } \\
\text { CBP } \\
\text { SSTS } \\
\text { SMP } \\
\text { PCCP }\end{array}$ & $\begin{array}{l}69 \% \\
10 \% \\
9 \% \\
9 \% \\
2 \%\end{array}$ & $\begin{array}{l}\text { BSS } \\
\text { CBP } \\
\text { SMP } \\
\text { SSTS } \\
\text { PCCP }\end{array}$ & $\begin{array}{l}61 \% \\
13 \% \\
12 \% \\
12 \% \\
1 \%\end{array}$ \\
\hline 14 & Motel & $\begin{array}{l}\text { BSS } \\
\text { CBP } \\
\text { SSTS } \\
\text { PCCP } \\
\text { Cons. Glass }\end{array}$ & $\begin{array}{l}55 \% \\
22 \% \\
21 \% \\
3 \% \\
0 \% \\
\end{array}$ & $\begin{array}{l}\text { BSS } \\
\text { SSTS } \\
\text { CBP } \\
\text { PCCP } \\
\text { Cons. Glass }\end{array}$ & $\begin{array}{l}44 \% \\
30 \% \\
25 \% \\
1 \% \\
0 \%\end{array}$ \\
\hline 15 & Hotel & $\begin{array}{l}\text { BSS } \\
\text { CBP } \\
\text { Other } \\
\text { SSTS } \\
\text { PCCP }\end{array}$ & $\begin{array}{l}54 \% \\
23 \% \\
10 \% \\
7 \% \\
6 \% \\
\end{array}$ & $\begin{array}{l}\text { BSS } \\
\text { CBP } \\
\text { Other } \\
\text { SSTS } \\
\text { PCCP }\end{array}$ & $\begin{array}{l}49 \% \\
18 \% \\
14 \% \\
13 \% \\
6 \%\end{array}$ \\
\hline \multicolumn{6}{|c|}{$\begin{array}{ll}\text { BSS }- \text { Brick, Stone, Stucco } & \text { PCCP }- \text { Pre-Cast Concrete Panel } \\
\text { CBP }- \text { Concrete, Block or Poured } & \text { SSTS }- \text { Siding, Shingles, Tiles, Shakes } \\
\text { SMP }- \text { Sheet Metal Panels } & \text { Cons. Glass }- \text { Construction Glass }\end{array}$} \\
\hline
\end{tabular}




\subsection{Mapping of CBECS Descriptors to ASHRAE Standard 90.1-2004 Wall Types}

ASHRAE Standard 90.1-2004 defines four wall types based on the functional performance of the wall: Mass Wall, Metal Building Wall, Steel Framed Wall, and Wood Framed and Other Wall. The primary assumption in setting the $90.1 \mathrm{U}$-factor requirements is that Mass Wall has continuous insulation, while Metal Building Wall has insulation compressed between metal members, possibly augmented by continuous insulation to decrease the overall U-factor. Steel Framed Wall and Wood Framed and Other Wall are simply frame walls with different structural members (and therefore different thermal bypass factors). It is important that the definition of Mass Wall in ASHRAE 90.1-2004 is a wall with a heat capacity exceeding (1) $7 \mathrm{Btu} / \mathrm{ft}^{2} \cdot{ }^{\circ} \mathrm{F}$ or (2) $5 \mathrm{Btu} / \mathrm{ft}^{2} \cdot{ }^{\circ} \mathrm{F}$ provided that the wall has a material unit weight not greater than $120 \mathrm{lb} / \mathrm{ft}^{3}$. Note that the $7 \mathrm{Btu} / \mathrm{ft}^{2} \cdot{ }^{\circ} \mathrm{F}$ is for any weight wall, while the $5 \mathrm{Btu} / \mathrm{ft}^{2} \cdot{ }^{\circ} \mathrm{F}$ is only for walls lighter than $120 \mathrm{lb} / \mathrm{ft}^{3}$. Thus, regardless of the actual type and placement of insulation, walls exceeding this level of heat capacity are treated as Mass Wall for setting of minimum U-Factor requirements. The definition of Mass Wall is such that a 4-inch brick facing on a frame wall construction does not create a Mass Wall under ASHRAE 90.1's definition.

Comparing the four ASHRAE Standard 90.1-2004 wall types with the 2003 CBECS wall descriptions indicates that the BSS description could conceivably be mapped to any one of the four ASHRAE 90.1 wall constructions. This is problematic because the BSS description is the single most common description in the 2003 CBECS for all the DOE Reference building types examined in this analysis. Relationships between the ASHRAE Standard 90.1-2004 roof types and the 2003 CBECS wall descriptions are shown in Table 4.2.

Table 4.2. Relationship of CBECS Wall Descriptions and ASHRAE Standard 90.1 Wall Constructions

\begin{tabular}{lcccc}
\hline & \multicolumn{4}{c}{ ASHRAE Standard 90.1 Wall Construction } \\
\cline { 2 - 5 } \multicolumn{1}{c}{ CBECS Wall Descriptions } & Mass Wall & $\begin{array}{c}\text { Metal } \\
\text { Building } \\
\text { Wall }\end{array}$ & $\begin{array}{c}\text { Steel- } \\
\text { Framed } \\
\text { Wall }\end{array}$ & $\begin{array}{c}\text { Wood Framed } \\
\text { and Other } \\
\text { Wall }\end{array}$ \\
\hline Brick, Stone, Stucco (BSS) & $\mathrm{X}$ & $\mathrm{X}$ & $\mathrm{X}$ & $\mathrm{X}$ \\
Concrete, Block or Poured (CBP) & $\mathrm{X}$ & & & \\
Pre-Cast Concrete Panels (PCCP) & $\mathrm{X}$ & & $\mathrm{X}$ & $\mathrm{X}$ \\
Sheet metal panels (SMP) & & & $\mathrm{X}$ & \\
Siding, Shingles, Tiles, Shakes (SSTS) & & & $\mathrm{X}$ & \\
$\begin{array}{l}\text { Decorative or Construction Glass } \\
\text { Window or Vision Glass }\end{array}$ & & & Unknown & Unknown \\
No Major Type & Unknown & Unknown & Unknown & Unknown \\
Other & Unknown & Unknown & Unknowny \\
\hline
\end{tabular}

The only unambiguous wall descriptions are CBP and PCCP, which are expected to fall under Standard 90.1's Mass Wall construction and SMP, which can be assumed to indicate Metal Building Walls. Buildings which report the use of decorative or construction glass or window or vision glass are believed to be very high WWR buildings (see discussion on gross wall area and WWR later in this report). Many of these buildings are likely some type of curtain-wall construction. Curtain-wall construction falls under the 90.1 construction category of Steel Framed Wall. 
The single most common opaque wall category in CBECS is BSS, which is also the most ambiguous category insofar as mapping to the 90.1 construction categories. Brick, stone, and stucco are all commonly used to dress up the façade of a building. However, brick and stone can both be the primary supporting construction material used in a building, and this is a common construction type in older buildings. The question of what is the underlying 90.1 construction is most important for establishing the baseline 90.1-2004 U-factor requirements, as well as the differential cost for modifications to the Reference building baseline building efficiency. However, any attempt to assign wall constructions to DOE Reference Buildings will undoubtedly require large doses of professional judgment. PNNL's expectation is that the relative fraction of brick or stone over metal building construction would be small, and the primary question is whether these brick, stone, or stucco façades are over masonry or frame walls.

Looking at specific Reference Building results in Table 4.1, we see the following:

- For large office buildings (tall office building under the current classification), the high fraction of pre-cast concrete use, along with some fraction of mass underlying the BSS seems to imply a near even split between a Metal Frame Wall (curtain wall) and a Mass Wall construction.

- For medium office and small office buildings it is clear that BSS predominates and that the obvious Mass Wall construction of CBP, or PCCP represents a small fraction of opaque wall area. $(<20 \%$ for medium offices and $<10 \%$ for small offices).

- For warehouse buildings, it appears that metal panels, indicative of metal building construction, would represent the most common post-1980 construction.

- For stand-alone retail building, metal panels appear to be the most common by wall area, although CBP is the most common by number of buildings. Experience suggest that a BSS façade (commonly brick) over a metal frame construction is the most common example for the BSS category and that Metal Frame underlying siding is also common for small retail. Thus this category as a whole seems to be nearly evenly split into thirds as Metal Buildings, Steel Frame (with BSS or siding façade) and Mass Wall (CBP or PCCP). This may partially be due to the wide range of building sizes in this category. No underlying single recommendation is forthcoming from CBECS.

- For primary school buildings, obvious Mass Wall construction (in this case CBP) represents less than $20 \%$ of wall area. Roughly $50 \%$ of wall area is in BSS construction, and roughly $20 \%$ is in siding or shingles. A relatively small fraction (7\%) is in metal panels.

- For secondary schools and university, $63 \%$ of wall area is in BSS construction, and roughly $26 \%$ is in obvious Mass Wall construction. A relatively small fraction (5\%) is in metal panels. When looking at number of buildings, siding (SSTS) seems to be relatively common but because it is very uncommon in terms of wall area, its use is assumed to be primarily for smaller buildings.

- For grocery stores, the obvious Mass Wall constructions (CBP, PCCP) taken together represent 31\% of wall area, slightly more than metal panels at 28\%. $16 \%$ is in the SSTS category, and $25 \%$ in BSS. Whether the most common 90.1 category is Mass Wall or a Frame Wall construction (mostly likely metal frame) depends on how much of BSS overlies masonry vs. frame wall. However, an even split of BSS between these two types of walls would suggest that overall Mass Wall construction was more common for this building type.

- For fast food restaurants the very high fraction of BSS suggest that little guidance as to underlying wall construction can come from CBECS. 
- For the restaurant category, there appears to be a slightly greater use of concrete construction than for siding and for metal panel walls, however BSS still makes up approximately $50 \%$ of the total wall area, and any decision on underlying wall structure will depend on how one classifies the BSS underlying construction.

- For the remaining Reference Building categories (hospital, outpatient health care, motels, and hotels) BSS makes up over $50 \%$ of the wall area. Looking at the relative predominance of masonry versus metal versus lightweight construction for the remaining categories, considering other data sources, and using personal observation may be the only way to assess the most common wall construction. Inspection of these other constructions coupled with experience suggests that for hospital and hotels, a Mass Wall construction is expected to be most likely and that for motels a Steel Frame Wall or Wood Frame Wall would be most likely. For outpatient health care the situation is less clear, with masonry (PCB and PCCP), SSTS, and metal wall all having roughly equal shares. No recommendation is forthcoming from CBECS

Based on this discussion, the suggestions shown in Table 4.3 can be made for DOE's Commercial Reference buildings.

Table 4.3. PNNL Proposed Wall Constructions Mapped to DOE Reference Buildings (Post-1980 Buildings, based on CBECS observations)

\begin{tabular}{cll}
\hline Reference Number & \multicolumn{1}{c}{ Reference Building Type } & \multicolumn{1}{c}{ Wall Construction } \\
\hline 1 & Large Office & Steel Frame Wall or Mass Wall \\
2 & Medium Office & No recommendation \\
3 & Small Office & No recommendation \\
4 & Warehouse & Metal Building Wall \\
5 & Stand-Alone Retail & No recommendation \\
6 & Strip Mall & NA \\
7 & Primary School & No recommendation \\
8 & Secondary School and University & No recommendation \\
9 & Grocery Store & Mass Wall \\
10 & Fast Food & No recommendation \\
11 & Restaurant & No recommendation \\
12 & Hospital & Mass Wall \\
13 & Outpatient Health Care & No recommendation \\
14 & Motel & Steel Frame Wall \\
15 & Hotel & Mass Wall \\
\hline
\end{tabular}

\subsection{Wall Construction Data from NC3}

In an attempt to provide a better estimate for wall construction for new buildings, data from the New Commercial Construction Characteristics (NC3) dataset was extracted. Table 4.4 presents the results of that extraction. While the sample size of NC3 is currently fairly low for most Reference building types (but currently being expanded), the results do provide some useful data. Table 4.4 shows the most common out of the three ASHRAE wall construction types by building count, floor area, wall area, and opaque wall area. 
Table 4.4. NC3 Wall Type Most Common 90.1 Wall Construction Type Results

\begin{tabular}{clccccc}
\hline & & & \multicolumn{2}{c}{ Most Common 90.1 Wall Construction Type by } \\
\cline { 4 - 7 } Reference & & Sample & Building & & & Opaque Wall \\
Number & Reference Building Type & Size & Count & Floor Area & Wall Area & Area \\
\hline 1 & Large office & 0 & NA & NA & NA & NA \\
2 & Medium office & 14 & Metal Frame & Metal Frame & Metal Frame & Metal Frame \\
3 & Small office & 19 & Masonry & Masonry & Masonry & Masonry \\
4 & Warehouse & 9 & Masonry & Masonry & Masonry & Masonry \\
5 & Stand-alone retail & 24 & Masonry & Metal Frame & Metal Frame & Masonry \\
6 & Strip Mall & 3 & Masonry & Masonry & Masonry & Masonry \\
7 & Primary School & 6 & Masonry & Masonry & Metal Frame & Metal Frame \\
8 & Secondary School and University & 7 & Metal Frame & Metal Frame & Metal Frame & Metal Frame \\
9 & Grocery Store & 9 & Metal Frame & Metal Frame & Metal Frame & Metal Frame \\
10 & Fast Food & 3 & Wood Frame & Wood Frame & Wood Frame & Wood Frame \\
11 & Restaurant & 13 & Metal Frame & Metal Frame & Metal Frame & Metal Frame \\
12 & Inpatient health care & 1 & Metal Frame & Metal Frame & Metal Frame & Metal Frame \\
13 & Outpatient health Care & 3 & Wood Frame & Wood Frame & Metal Frame & Metal Frame \\
14 & Motel & 2 & (a) & Masonry & Masonry & Masonry \\
15 & Hotel & 4 & Metal Frame & Metal Frame & Metal Frame & Metal Frame \\
& Total & 117 & & & & \\
\hline
\end{tabular}

(a) equal masonry and wood

Note. When calculating wall area statistics, sample sizes for medium office, small office, standalone retail, and secondary school and university are one smaller than sample sizes shown (due to the fact that one building in each of these Reference Building categories does not have a wall area listed).

Of note in the above table is that for small office, masonry was $53 \%$ of the opaque wall area. For warehouses it was $69 \%$ of the opaque wall area and for strip malls it was $76 \%$ of the opaque wall area. Each of these suggests that a Mass Wall was appropriate for the building types. For Primary Schools, $72 \%$ of opaque wall was metal frame. This dropped to $57 \%$ for secondary schools, but was $62 \%$ of outpatient health care. Restaurants were nearly evenly split between metal and wood frame (47\% to $41 \%$ respectively). Fast food restaurants were also nearly evenly split between wood frame $(53 \%)$ and masonry $(47 \%)$.

Table 4.5 offers recommendations based on a combination of the NC3 results in Table 4.4 and the CBECS results in Table 4.3. In this table, NC3 results were used to provide wall types for Reference buildings where CBECS recommendations were unclear. No attempt was made to replace the suggestions derived from CBECS shown in Table 4.3 with those from NC3. 
Table 4.5. Proposed Wall Constructions by Building Type (Post-1980 Buildings) Based on CBECS and NC3 Data

\begin{tabular}{cll}
\hline Reference Number & \multicolumn{1}{c}{ Reference Building Type } & \multicolumn{1}{c}{ Wall Construction } \\
\hline 1 & Large Office & Steel Frame Wall or Mass Wall \\
2 & Medium Office & Steel Frame Wall \\
3 & Small Office & Mass Wall \\
4 & Warehouse & Metal Building Wall \\
5 & Stand-Alone Retail & Steel Frame Wall or Mass Wall \\
6 & Strip Mall & Mass Wall \\
7 & Primary School & Steel Frame Wall \\
8 & Secondary School and University & Steel Frame Wall \\
9 & Grocery Store & Mass Wall \\
10 & Fast Food & Wood Frame Wall \\
11 & Restaurant & Steel Frame Wall \\
12 & Hospital & Mass Wall \\
13 & Outpatient Health Care & Steel Frame Wall \\
14 & Motel & Steel Frame Wall \\
15 & Hotel & Mass Wall \\
\hline
\end{tabular}

\subsection{Consideration of Gross Wall Area}

Certain commercial building types may be found with large amounts of glass. In some climates, large office buildings tend to be basically glass boxes. In considering opaque wall area, we intentionally ignored the responses for wall types that involved construction or vision glass. In this section, we consider the gross wall area in order to estimate the percentage of the gross wall area that is glazed. If the wall construction data in the 2003 CBECS is examined, the only Reference building type where the wall construction was categorized as glass with significant frequency was large office at $7.8 \%$ (4.9\% of gross wall area in buildings with the Wall Construction [WCNS] statistics as decorative or construction glass and $2.9 \%$ of gross wall area in buildings listed as window or vision glass).

The numbers in Table 4.6 show almost trivial amounts of glass in Reference building types. The reason for this is that the question asked in the 2003 CBECS was about the primary wall construction, not about the windows. Building scientists tend to view the wall as containing both opaque elements and fenestration, but the typical respondent to the CBECS survey does not consider windows to be walls.

We emphasize that these are categories of primary wall construction. When vision or construction glass is under discussion, the decision of whether a high WWR building wall construction should be considered glass or masonry or metal or other underlying opaque structure may be highly subjective. Upon further examination, we note that of all the individual CBECS 2003 observations that fall in the $76-100 \%$ exterior glass category (82 observations across all years), only 29 show 'window or vision' glass as the wall construction and 9 show 'decorative or construction glass' as the wall construction. The majority of these very high WWR buildings have 'wall construction' classed as another (opaque) construction material. Similarly, of the 295 observations in the 50\% - 75\% WWR category, only 26 list glass as the construction type. 
Table 4.6. Fraction of Total Wall Area in Reference Building Category in Buildings Reporting 'Glass' for Wall Construction Material (Post-1980 Buildings)

\begin{tabular}{clccc}
\hline $\begin{array}{c}\text { Reference } \\
\text { Number }\end{array}$ & Reference Building Type & $\begin{array}{c}\text { Decorative or } \\
\text { construction glass }\end{array}$ & $\begin{array}{c}\text { Window or } \\
\text { vision glass }\end{array}$ & Total Glass \\
\hline 1 & Large Office & $5.7 \%$ & $12.3 \%$ & $18.0 \%$ \\
2 & Medium Office & $0.4 \%$ & $5.9 \%$ & $6.3 \%$ \\
3 & Small Office & $0.7 \%$ & $1.0 \%$ & $1.8 \%$ \\
4 & Warehouse & $0.5 \%$ & $0.0 \%$ & $0.5 \%$ \\
5 & Stand-alone Retail & $0.0 \%$ & $0.0 \%$ & $0.0 \%$ \\
6 & Strip Mall & $\mathrm{NA}$ & $\mathrm{NA}$ & $\mathrm{NA}$ \\
7 & Primary School & $0.8 \%$ & $0.0 \%$ & $0.8 \%$ \\
8 & Secondary School and University & $0.0 \%$ & $1.1 \%$ & $1.1 \%$ \\
9 & Grocery Store & $0.0 \%$ & $0.0 \%$ & $0.0 \%$ \\
10 & Fast Food & $0.0 \%$ & $2.8 \%$ & $2.8 \%$ \\
11 & Restaurant & $0.0 \%$ & $0.9 \%$ & $0.9 \%$ \\
12 & Hospital & $1.6 \%$ & $0.0 \%$ & $1.6 \%$ \\
13 & Outpatient Health Care & $0.0 \%$ & $0.0 \%$ & $0.0 \%$ \\
14 & Motel & $0.0 \%$ & $0.0 \%$ & $0.0 \%$ \\
15 & Hotel & $0.0 \%$ & $0.0 \%$ & $0.0 \%$ \\
\hline
\end{tabular}

\subsection{Window to Wall Area}

Having noted that the use of wall construction data in the 2003 CBECS is not an adequate way to estimate glass area, we next looked at CBECS data for reported percent exterior glass. As noted previously, CBECS uses five different categories for classifying the percent exterior glass for each building (WWR categories) for those buildings reporting this statistic. Table 4.6 shows the fraction of total wall area (opaque and glass area) calculated for each Reference building category that falls in each WWR category, again using the percent exterior glass assumptions from Table 2.2 (the midpoint of each WWR range) and ignoring buildings where the WWR area statistic was not reported. Table 4.7 also shows the average window area to total wall area ratio calculated for each Reference Building category. The category that contains the most observations (the most typical) for Reference building type is shown in bold font.

Table 4.8 shows the number of buildings represented by the CBECS data set in each WWR bin. The category that contains the most observations (the most typical) for Reference building type is shown in bold font. In general, the most common bin shown in Table 4.8 for each Reference Building agrees with the Table 4.7 results for the bin with the highest calculated overall wall area. However, this was not true in the case of hospitals, primary schools, or outpatient healthcare by a small margin. 
Table 4.7. Window-to-Wall Area Fraction for Post-1980 Buildings (total window area divided by total wall area) $)^{\text {(a) }}$

\begin{tabular}{clcccccc}
\hline $\begin{array}{c}\text { Reference } \\
\text { Number }\end{array}$ & Reference Building Type & $\begin{array}{c}10 \text { percent } \\
\text { or less }\end{array}$ & $\begin{array}{c}11 \text { to } 25 \\
\text { percent }\end{array}$ & $\begin{array}{c}26 \text { to } 50 \\
\text { percent }\end{array}$ & $\begin{array}{c}51 \text { to } 75 \\
\text { percent }\end{array}$ & $\begin{array}{c}76 \text { to } 100 \\
\text { percent }\end{array}$ & $\begin{array}{c}\text { Average } \\
\text { WWR }\end{array}$ \\
\hline 1 & Large Office & $0 \%$ & $13 \%$ & $26 \%$ & $\mathbf{4 7 \%}$ & $13 \%$ & $54 \%$ \\
2 & Medium Office & $17 \%$ & $\mathbf{3 7 \%}$ & $27 \%$ & $14 \%$ & $6 \%$ & $31 \%$ \\
3 & Small Office & $\mathbf{4 3 \%}$ & $34 \%$ & $16 \%$ & $6 \%$ & $1 \%$ & $19 \%$ \\
4 & Warehouse & $\mathbf{9 2 \%}$ & $6 \%$ & $1 \%$ & $0 \%$ & $0 \%$ & $6 \%$ \\
5 & Stand-alone Retail & $\mathbf{6 6 \%}$ & $27 \%$ & $6 \%$ & $1 \%$ & $0 \%$ & $11 \%$ \\
6 & Strip Mall & $\mathrm{NA}$ & $\mathrm{NA}$ & $\mathrm{NA}$ & $\mathrm{NA}$ & $\mathrm{NA}$ & $\mathrm{NA}$ \\
7 & Primary School & $35 \%$ & $\mathbf{3 6 \%}$ & $21 \%$ & $5 \%$ & $2 \%$ & $22 \%$ \\
8 & Secondary School and University & $26 \%$ & $\mathbf{4 8 \%}$ & $19 \%$ & $8 \%$ & $0 \%$ & $22 \%$ \\
9 & Grocery Store & $\mathbf{8 1 \%}$ & $19 \%$ & $0 \%$ & $0 \%$ & $0 \%$ & $7 \%$ \\
10 & Fast Food & $18 \%$ & $21 \%$ & $\mathbf{3 7 \%}$ & $25 \%$ & $0 \%$ & $34 \%$ \\
11 & Restaurant & $27 \%$ & $\mathbf{4 0 \%}$ & $21 \%$ & $12 \%$ & $0 \%$ & $24 \%$ \\
12 & Hospital & $16 \%$ & $\mathbf{4 1 \%}$ & $34 \%$ & $7 \%$ & $1 \%$ & $27 \%$ \\
13 & Outpatient Health Care & $35 \%$ & $\mathbf{3 6 \%}$ & $21 \%$ & $8 \%$ & $0 \%$ & $21 \%$ \\
14 & Motel & $27 \%$ & $\mathbf{3 9 \%}$ & $28 \%$ & $3 \%$ & $3 \%$ & $24 \%$ \\
15 & Hotel & $2 \%$ & $36 \%$ & $\mathbf{4 5 \%}$ & $16 \%$ & $0 \%$ & $34 \%$ \\
\hline
\end{tabular}

(a) Window area fractions developed consider only those buildings where WWR was reported. For all buildings but office, the fraction not reporting is small $(<12 \%$ of wall area not reporting, $<10.5 \%$ of buildings by buildings represented). For Large Office however, the fraction not reporting added up to $27 \%$ of total wall area and $15.4 \%$ buildings represented.

Table 4.8. Fraction of Buildings in Each Window-to-Wall Ratio Bin (Post-1980 Buildings)

\begin{tabular}{clccccc}
\hline $\begin{array}{c}\text { Reference } \\
\text { Number }\end{array}$ & Reference Building Type & $\begin{array}{c}10 \text { percent } \\
\text { or less }\end{array}$ & $\begin{array}{c}11 \text { to } 25 \\
\text { percent }\end{array}$ & $\begin{array}{c}26 \text { to } 50 \\
\text { percent }\end{array}$ & $\begin{array}{c}51 \text { to } 75 \\
\text { percent }\end{array}$ & $\begin{array}{c}76 \text { to } 100 \\
\text { percent }\end{array}$ \\
\hline 1 & Large Office & $0 \%$ & $16 \%$ & $29 \%$ & $\mathbf{3 9 \%}$ & $17 \%$ \\
2 & Medium Office & $25 \%$ & $\mathbf{4 3 \%}$ & $23 \%$ & $7 \%$ & $3 \%$ \\
3 & Small Office & $\mathbf{4 7 \%}$ & $35 \%$ & $11 \%$ & $6 \%$ & $1 \%$ \\
4 & Warehouse & $\mathbf{9 7 \%}$ & $3 \%$ & $1 \%$ & $0 \%$ & $0 \%$ \\
5 & Stand-alone Retail & $\mathbf{6 6 \%}$ & $26 \%$ & $7 \%$ & $1 \%$ & $0 \%$ \\
6 & Strip Mall & $\mathrm{NA}$ & $\mathrm{NA}$ & $\mathrm{NA}$ & $\mathrm{NA}$ & $\mathrm{NA}$ \\
7 & Primary School & $\mathbf{4 8 \%}$ & $32 \%$ & $14 \%$ & $5 \%$ & $1 \%$ \\
8 & Secondary School and University & $39 \%$ & $\mathbf{4 3 \%}$ & $13 \%$ & $4 \%$ & $0 \%$ \\
9 & Grocery Store & $\mathbf{6 5 \%}$ & $35 \%$ & $0 \%$ & $0 \%$ & $0 \%$ \\
10 & Fast Food & $17 \%$ & $22 \%$ & $\mathbf{3 9 \%}$ & $22 \%$ & $0 \%$ \\
11 & Restaurant & $25 \%$ & $\mathbf{4 3 \%}$ & $19 \%$ & $12 \%$ & $0 \%$ \\
12 & Hospital & $23 \%$ & $35 \%$ & $\mathbf{3 8 \%}$ & $3 \%$ & $1 \%$ \\
13 & Outpatient Health Care & $\mathbf{4 9 \%}$ & $36 \%$ & $13 \%$ & $2 \%$ & $0 \%$ \\
14 & Motel & $27 \%$ & $\mathbf{4 5 \%}$ & $26 \%$ & $1 \%$ & $1 \%$ \\
15 & Hotel & $6 \%$ & $36 \%$ & $\mathbf{4 9 \%}$ & $10 \%$ & $0 \%$ \\
\hline
\end{tabular}

(a) Fraction of buildings statistic considers only those buildings where WWR was reported. For all buildings but office, the fraction not reporting was small $(<10.5 \%$ of buildings by buildings represented). For Large Office however, the fraction not reporting added up $15.4 \%$ buildings represented. 


\subsection{Distribution of Glazing}

CBECS 2003 also reports whether or not the glass in a building is distributed equally on all sides or not with the Equal Glass (EQGLS) statistic. The CBECS 2003 data for post-1980 buildings is shown in Table 4.9, based on buildings represented in the population. If apparent that a building sample was heavily weighted ( $60 \%$ or greater) toward equal or unequal dispersion, we have noted this in the last two columns. ${ }^{1}$ Where the weighting was more or less equivalent, we have not suggested an approach, although it may make more sense from a modeling perspective to presume equal orientation.

Fast food restaurants appear to us an anomaly, as personal experience suggests that few, if any, have equal glazing on all sides. Rather, the glass is likely equally distributed in the dining area, but kitchen areas are seldom glazed. Our suggestion would be that these also be modeled as unequally distributed glazing (this conclusion was strongly borne out in the pre-1980 building examination).

Table 4.9. Distribution of Glazing for Post-1980 Buildings

\begin{tabular}{clcccc}
\hline $\begin{array}{c}\text { Reference } \\
\text { Number }\end{array}$ & Reference Building Type & $\begin{array}{c}\text { Fraction of } \\
\text { Buildings with } \\
\text { Equal Glazing } \\
\text { Distribution }\end{array}$ & $\begin{array}{c}\text { Fraction of } \\
\text { Buildings with } \\
\text { Unequal Glazing } \\
\text { Distribution }\end{array}$ & $\begin{array}{c}\text { More } \\
\text { Equally } \\
\text { Dispersed }\end{array}$ & $\begin{array}{c}\text { Less } \\
\text { Equally } \\
\text { Dispersed }\end{array}$ \\
\hline 1 & Large Office & $94 \%$ & $6 \%$ & $\mathrm{X}$ & \\
2 & Medium Office & $66 \%$ & $34 \%$ & $\mathrm{X}$ & \\
3 & Small Office & $42 \%$ & $58 \%$ & & $\mathrm{X}$ \\
4 & Warehouse & $66 \%$ & $34 \%$ & $\mathrm{X}$ & $\mathrm{X}$ \\
5 & Stand-alone Retail & $19 \%$ & $81 \%$ & & \\
6 & Strip shopping mall & NA & NA & & \\
7 & Primary School & $60 \%$ & $40 \%$ & $\mathrm{X}$ & $\mathrm{X}$ \\
8 & Secondary School and University & $51 \%$ & $49 \%$ & & $\mathrm{X}$ \\
9 & Grocery Store & $12 \%$ & $88 \%$ & & $\mathrm{X}$ \\
10 & Fast Food & $42 \%$ & $58 \%$ & & $\mathrm{X}$ \\
11 & Restaurant & $23 \%$ & $77 \%$ & & $\mathrm{X}$ \\
12 & Hospital & $77 \%$ & $23 \%$ & & \\
13 & Outpatient Health Care & $47 \%$ & $53 \%$ & & \\
14 & Motel & $59 \%$ & $41 \%$ & & \\
15 & Hotel & $65 \%$ & $35 \%$ & & $\mathrm{X}$ \\
\hline
\end{tabular}

\footnotetext{
${ }^{1}$ There were three building types were heavily weighted one way or the other, but not quite at $60 \%$. These include motel at 59\% equally distributed and small office and fast food at $58 \%$ unequal distribution. These are marked as though they were heavily weighted as the $60 \%$ cutoff is fairly arbitrary.
} 


\subsection{References}

Deru M. and B. Griffith. 2006. DOE Commercial Building Research Benchmarks For New Commercial Buildings. Third Draft. National Renewable Energy Laboratory. Golden CO.

DOE EIA. 1992. 1992 Commercial Building Energy Consumption Survey (CBECS). Energy

Information Administration. US Department of Energy. Washington DC. All released data on the 1992 CBECS may be found at http://www.eia.doe.gov/emeu/cbecs/.

DOE EIA. 2003. 2003 Commercial Building Energy Consumption Survey (CBECS). Energy

Information Administration. US Department of Energy. Washington DC. All released data on the 2003 CBECS may be found at http://www.eia.doe.gov/emeu/cbecs/.

Richman EE, JR Williams, RK Biyani, and SC Gaines. 2004. "Energy-Related Commercial Building Construction Characteristics: An Assessment of National Current Practice and Energy Code Compliance." In 2004 ACEEE Summer Study on Energy Efficiency in Buildings, p. 12 pp. American Council for an Energy-Efficient Economy, Washington, DC.

Winiarski, DE, MA Halverson, W Jiang. 2007. Analysis of Building Envelope Construction in 2003 CBECS: Pre-1980 Buildings. PNNL-SA-55594. Pacific Northwest National Laboratory, Richland, WA. 

Appendix A

Development of Aspect Ratio Data for Odd Shaped Building 



\section{Appendix A}

\section{Development of Aspect Ratio Data for Odd Shaped Building}

Aspect ratios are important in determining the relative amount of perimeter area (responsive to the outdoor environment and with window daylighting potential) to core area for a given building. Aspect ratio information coupled with orientation and self -shading would also be relevant in determining solar loading in a real building. Unfortunately aspect ratio information has not been collected in the DOE/EIA CBECS since 1992, so general information on actual aspect ratios has been limited. What information was collected in these early CBECS distributions was solely for rectangular buildings. Several of the CBECS versions have also captured data on building shape. Table A.1 shows how the CBECS 2003 categorizes building shape, as well as the fraction of buildings in the data set in each shape category.

Table A.1. Shape Categories in 2003 CBECS

\begin{tabular}{lc}
\hline CBECS 2003 Shape Categories & $\begin{array}{c}\text { Fraction of Building } \\
\text { Population }\end{array}$ \\
\hline No response & $16 \%$ \\
+ or cross shaped & $2 \%$ \\
E shaped & $1 \%$ \\
H shaped & $2 \%$ \\
L shaped & $5 \%$ \\
T shaped & $2 \%$ \\
U shaped & $2 \%$ \\
Narrow rectangle & $6 \%$ \\
Other shape & $4 \%$ \\
Rectangle/square with courtyard & $3 \%$ \\
Square & $9 \%$ \\
Wide rectangle & $47 \%$ \\
Total & $100 \%$ \\
\hline
\end{tabular}

CBECS 2003 categorized $62 \%$ of the buildings as either rectangular or square (ignoring those rectangular or square buildings with courtyards), and showed $16 \%$ of the buildings as not reporting a shape. The remaining $22 \%$ of buildings have more elaborate shapes. While data for estimating aspect ratios is unavailable in $\mathrm{CBEC}$, it is clear that these more elaborate shapes represent a substantial fraction of buildings. Some thinking as to reasonable building design can help in assessing likely equivalent aspect ratios for these elaborately shaped buildings. Equivalent aspect ratio here refers to rectangular buildings with perimeter length to core area ratios equivalent to the original building; they are developed to estimate the wall and window fraction in the general population, but are also useful in developing revised aspect ratios for the Reference buildings.

Picture an L-shaped building with two equal length legs. This is shown below with each leg having an outside length of 2 units and width of 1 unit. See Figure A.1 below with roughly drawn images and dimensions shown. The ratio of the perimeter, $\mathrm{P}$, for this building to the Area, A, of the building is $8: 3$. A rectangular building with an aspect ratio of 3 has the same ratio of $\mathrm{P}: \mathrm{A}$. It is not hard to envision bending one of the L legs around the corner of the building to form the rectangle with this aspect ratio. Sliding one of the legs toward the middle of the other leg forms a T-shaped building of similar dimensions. Such a building would also have an equivalent aspect ratio of 3 . 

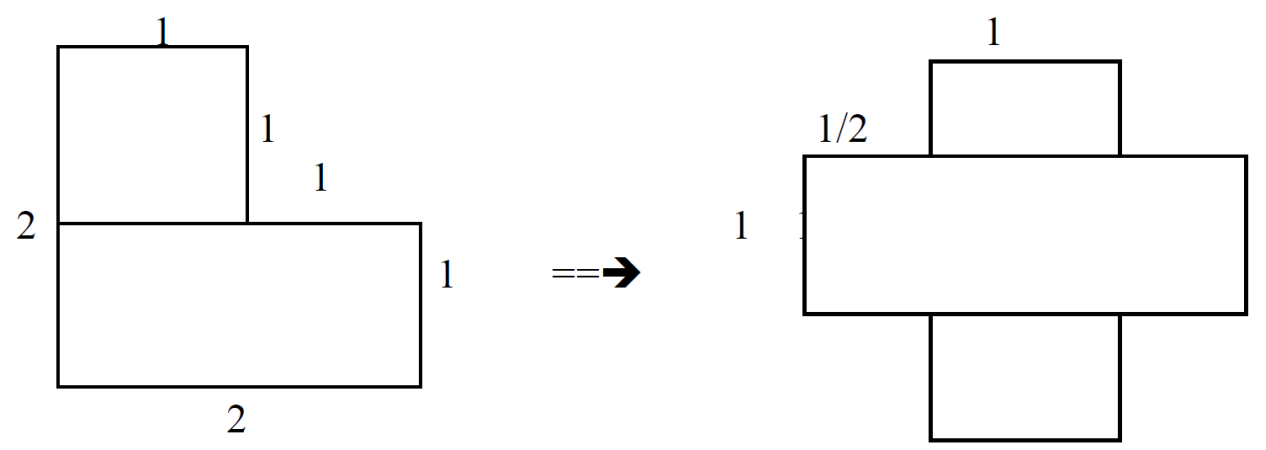

Figure A.1. L-Shaped and T-Shaped Buildings

A U-shaped building might look like the picture below (with the unit dimensions shown). Assume a total linear dimension of 12 for the perimeter and an area of 5. This could be thought of as a building with an aspect ratio of 5 . (Rotate the arms of the $U$ to the sides to stretch the shape into a line, and you get a 5 unit by 1 unit rectangle.

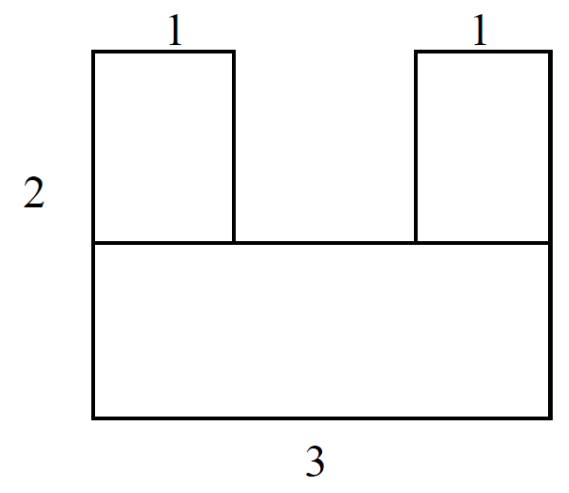

Figure A.2. U-Shaped Building

An H-shaped building could look like the structure below, with a perimeter to area ratio similar to the U-shaped building above (12:5) and equivalent to that of a rectangle with an aspect ratio of 5.

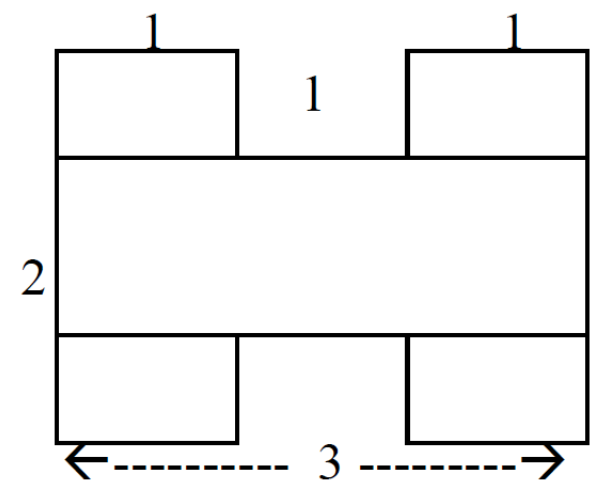

Figure A.3. H-Shaped Building 
Other building shapes in CBECS include buildings shaped like a cross, buildings shaped like an E, as well as other, less identified building shapes. Dimensions for the lengths of individual elements for all of the shapes discussed are not documented in CBECS, so actual equivalent aspect ratios could not be calculated. However the dimensions used above appear to reflect reasonable building design based on experience. The simplifying assumption made for this analysis was that all non rectangular shapes would be given an aspect ratio of 4 . This allows inclusion of non-rectangular buildings in this analysis and provides a more reasonable assessment of perimeter loads in the general building population. In the future, the NC3 data set may be able to provide greater insight for developing equivalent aspect ratios. 



\section{Distribution}

No. of

Copies

\# Name

Organization

Address

City, State and ZIP Code

\# Organization

Address

City, State and ZIP Code

Name

Name

Name

Name

Name (\#)

\# Name

Organization

Address

City, State and ZIP Code
No. of

\section{Copies}

\# Foreign Distribution

\# Name

Organization

Address

Address line 2

COUNTRY

\# Local Distribution

Pacific Northwest National Laboratory

Name

Name

Name

Name

Name
Mailstop

Mailstop

Mailstop

Mailstop

(PDF) 




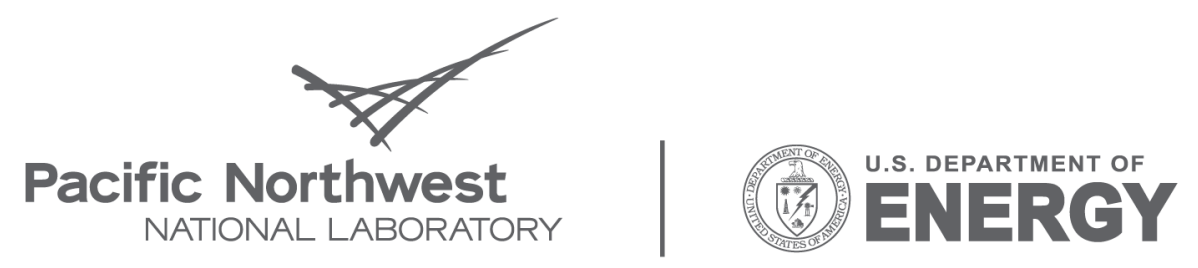

Proudly Operated by Battelle Since 1965

902 Battelle Boulevard

P.O. Box 999

Richland, WA 99352

1-888-375-PNNL (7665)

www.pnl.gov 